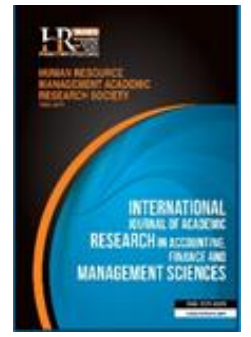

International Journal of Academic Research in Accounting, Finance and Management Sciences

Vol. 10, No.2, April 2020, pp. 157-170

E-ISSN: 2225-8329, P-ISSN: 2308-0337

(c) 2020 HRMARS

www.hrmars.com

To cite this article: Oshiole, S., Elamah, A. F., Ndubuisi, A. N. (2020). Effect of Environmental Cost Disclosure on Profitability of Listed Oil and Gas Firms in Nigeria., International Journal of Academic Research in Accounting, Finance and Management Sciences 10 (2):157-170

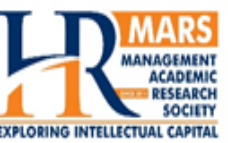

\title{
Effect of Environmental Cost Disclosure on Profitability of Listed Oil and Gas Firms in Nigeria
}

\author{
Samuel Oshiole ${ }^{1}$, Aruna, Fatai Elamah ${ }^{2}$, Amahalu, Nestor Ndubuisi $^{3}$ \\ ${ }^{1}$ Department of Accountancy, Auchi Polytechnic Auchi, Edo State, Nigeria, ${ }^{1}$ E-mail: bigsam031@yahoo.com \\ ${ }^{2}$ Hartland Nigeria Limited, Auchi, Edo State, Nigeria, ${ }^{2}$ E-mail: elamselams@gmail.com \\ ${ }^{3}$ Department of Accountancy, Nnamdi Azikiwe University Awka, Anambra State, Nigeria, \\ ${ }^{3}$ E-mail:nn.amahalu@unizik.edu.ng
}

\begin{abstract}
The objective of this study was to ascertain the effect of environmental cost disclosure on profitability of oil and gas firms listed on Nigeria Stock Exchange between 2010 and 2019. Eleven (11) listed oil and gas firms were purposively sampled. The proxies for environmental cost disclosure include waste management cost disclosure, employee health and safety cost disclosure and environmental remediation cost, while net profit margin was employed as profitability measure. Content analysis was employed while Pearson Correlation Coefficient and Panel Least Square (PLS) Regression analysis via STATA 13 statistical software were used to test the hypotheses of the study. The result of this study showed that waste management cost disclosure, employee health and safety cost disclosure and environmental remediation cost disclosure have a significant positive effect on net profit margin at $5 \%$ level of significance respectively. This study therefore recommends inter alia that since environmental cost is value relevant in making strategic business decision. Thus, oil and gas firms should constantly reposition their accounting system in order to provide information on environmental cost so that the true costs in an organization can be ascertained and properly allocated.
\end{abstract}

Key words

Environmental Cost, Profitability, Remediation Cost

Received: 16 May 2020 (C) The Authors 2020

Revised: 30 Jun 2020 Published by Human Resource Management Academic Research Society (www.hrmars.com)

Accepted: $\quad 08 \mathrm{Jul} 2020$ This article is published under the Creative Commons Attribution (CC BY 4.0) license. Anyone may Published Online: $27 \mathrm{Jul} 2020$ reproduce, distribute, translate and create derivative works of this article (for both commercial and non-commercial purposes), subject to full attribution to the original publication and authors. The full terms of this license may be seen at: http://creativecommons.org/licences/by/4.0/legalcode

\section{Introduction}

The use of natural resources and continuous emissions of greenhouse gases by industries around the world are on increase. This is traceable to industrial revolution of late $18^{\text {th }}$ century where economic activities in many areas moved from agriculture to manufacturing. Production shifted from its traditional locations in the home and thatched workshops to factories. The industrial revolutions lead to economic improvement for most people in the industrialized society. These economic developments are not without costs. Industrialization which required the use of natural resources including energy brought about factory pollutant and greater land use, which harmed the natural environment. This is evidenced in environmental degradation and atmospheric pollution generally experienced in the world and particularly in Nigeria today. However, the increase in global environmental awareness and the campaign for sustainable economic development is redirecting the attention of firms towards environmental sensitivity. Sustainable development as is generally known focuses on the creation of wealth and prosperity, whilst considering the true importance of social and environmental aspects, allowing business and public organizations to meet triple bottom line in sustainable management. The search for sustainability has made various global 
institutions to set out policies that guide human interaction with the environment. These guidelines have great effect on corporations, as they are made to understand that their business strategies affect the society, can influence behaviour and disorganize the physical, social and economic environment (Ezeokafor \& Amahalu, 2019).

Environmental accounting, as defined by Ministry of Environment (2002) in "Environmental Accounting Guidelines", is an account aimed at achieving sustainable development, maintaining a favorable relationship with the community, and pursuing effective and efficient environmental conservation activities. This type of accounting enables a company to ascertain the cost of conserving the environment while carrying out her normal business activities, discover benefits and gains from such activities, and provide the best means possible for quantitative measurement and encourage the communication of the results. Proper disclosure of accounting information relating to the environment is a very important aspect of accountability. Environmental cost disclosure enables companies and other organizations to increase their public trust and confidence. This however will lead to fair assessment of the organizations. According to an environmental protection agency based in USA, environmental costs include costs of complying with environmental laws. The agency specifically stated that it includes environmental remediation costs, pollution control equipment costs and non-compliance penalty. Based on the meaning of environmental degradation, environmental cost could also cover the cost incurred to prevent degradation, cost of restating the environment to its original state, cost of restoring depleted environment to its normal position. Profit ascertainment requires the subtraction of recurrent costs from revenues. Most often, the cost that leads to changes in the environment, which affect people adversely and cause damages to the environment, are not taken into consideration before profits are determined. In other words, the profits could be wrongly determined. The result of this, in most cases, is reporting of wrong and excessive profits which will also mislead the decision makers (Norhasimah et al., 2016). The measure of environmental performance and propensity increasingly emphasizes the awareness and empowerment of stakeholders. The regulation of environmental performance seems to depend crucially on the content and quality of environmental information disclosure. The stakeholders pay much attention to environmental information disclosure and environmental risk measure with an increase of environmental risk and market risk, and they are anxious to capture more environmental information disclosure and improve environmental risk management. Currently it is widely believed that social responsibility reporting, sustainable development reporting and environmental-protection reporting constitute an effective and efficient way to understand environmental performance and environmental risks. Most firms naturally seek the goodwill of neighboring communities, employees, stockholders, investors, financial institutions, local government and citizens. The widely spreading of environmental responsibility and information has a significant impact on stakeholders' interests.

\subsection{Statement of the Problem}

Environmental cost disclosure is an issue that has captured the attention of national and international, political and business leaders across the globe and the developed world. The creation of wealth has led to various environmental impacts such as depletion of non-renewable resources, global warming, diminution of land resources, acidification, reduction of water resources and potential threats to health and safety of employees. The issue of environmental abuses and degradation has led various sectors, governments and non-governmental organizations (NGOs) to engage with environmental sustainability debates and initiate strategies for responding to the challenges of sustainable development.

The environment has a long history of being regarded as unrelated to the economic system (Amahalu et al., 2018). Businesses for many decades have ignored the impact of their activities on the natural and social environment in which they operated, unless it had direct repercussions on the profit and loss account. However, the neglect by business of the negative externalities arising from the pursuit of economic objectives along with various environmental abuses by companies (e.g. Royal Dutch/Shell Brent Spar dumping and Ogoni crises in 1995 and BP's Gulf of Mexico rig explosion in 2010) have created less than positive attitudes amongst stakeholders towards business. Rodriguez \& Cruz (2017) argued that customers are gradually altering their purchasing attitudes towards behaviour that is more sensitive to the natural and social environment. This then risks a tarnished image for those firms not taking environmental 
issues seriously. Despite the rising interest in environmental issues, there have been divergent views regarding the nature of the relationship between corporate environmental cost disclosure and profitability. The findings from research to date are equivocal. Some studies purport to find a positive relationship (Amahalu et al., 2017; Russo \& Fouts, 2017; Judge \& Douglas, 2018). Similar studies found a negative relationship (Thornton et al., 2013; Worrell et al., 2015). While others showed either inconclusive results or no (neutral) effect (King \& Lenox, 2010; Rockness et al., 2016).

From the foregoing it is crystal clear that there is a gap in knowledge. In order to resolve the obvious research gap left by the literature in terms of inconclusive outcomes from previous similar studies, to uncover specific and novel evidence that may account for the variability in earlier study outcomes, this study focused on upstream oil and gas companies in Nigeria from 2010-2019; generating three different explanatory data sets (employee health and safety cost disclosure, waste management cost disclosure and environmental remediation cost disclosure).

\subsection{Objectives of the Study}

The major objective of the study is to ascertain the effect of Environmental Cost Disclosure on Profitability of Oil and Gas firms listed on Nigeria Stock Exchange. The specific objectives are designed to:

i. Ascertain the effect of Waste Management Cost Disclosure on Net Profit Margin of Oil and Gas Companies listed on Nigeria Stock Exchange.

ii. Determine the effect of Employee Health and Safety Cost Disclosure on Net Profit Margin of Oil and Gas Companies listed on Nigeria Stock Exchange.

iii. Evaluate the effect Environmental Remediation Cost Disclosure on Net Profit Margin of Oil and Gas Companies listed on Nigeria Stock Exchange.

\subsection{Research Hypotheses}

In order to address the issue raised above, the following were hypothesized in null form:

$\mathrm{Ho}_{1}$ : Waste Management Cost Disclosure has no significant effect on Net Profit Margin of Oil and Gas Companies listed on Nigeria Stock Exchange.

$\mathrm{Ho}_{2}$ : Employee Health and Safety Cost Disclosure has no significant effect on Net Profit Margin of Oil and Gas Companies listed on Nigeria Stock Exchange.

$\mathrm{Ho}_{3}$ : Environmental Remediation Cost Disclosure has no significant effect on Net Profit Margin of Oil and Gas Companies listed on Nigeria Stock Exchange.

\section{Literature review}

\subsection{Environmental Cost Disclosure}

Environmental costs are costs connected with the actual or potential deterioration of natural assets due to economic activities. Such costs can be viewed from two different perspectives, namely as (a) costs caused, that is, costs associated with economic units actually or potentially causing environmental deterioration by their own activities or as (b) costs borne, that is, costs incurred by economic units independently of whether they have actually caused the environmental impacts (Glossary of Environment Statistics, 2001). Environmental costs are one of the many different types of costs, businesses incur as they provide goods and services to their customers. Environmental performance is one of the many important measures of business success (Ezeokafor \& Amahalu, 2019).

\subsection{Waste Management Cost Disclosure}

Waste (or wastes) is unwanted or unusable materials. Waste is any substance which is discarded after primary use, or is worthless, defective and of no use.Examples includes municipal solid waste (household trash/refuse), hazardous waste, wastewater (such as sewage, which contains bodily wastes (feces and urine) and surface runoff), radioactive waste, and others. Wastes are substance or objects, which are disposed of or are intended to be disposed of or are required to be disposed of by the provisions of national law (UNSD Glossary of Environment Statistics, 2013). Waste collection and transport can generate up to $70 \%$ of the total costs of the system. Separated collection of recyclables implies additional 
costs for which the sale of recycled waste often does not compensate, but there is increased pressure to reach the long-term recycling objectives set by law. The proper estimation and monitoring of waste collection costs are essential to define the most cost-effective waste collection system (Dijkgraaf \& Gradus, 2017).

\subsection{Employee Health and Safety Cost Disclosure}

Employee Health and Safety Cost is a great way for employees to learn additional skills and knowledge and to reinforce quality work practices which will result in a change in workplace behaviour. Investing in effective employee training will increase skills, knowledge, productivity and morale as well as replace and avoid workplace incidents. Health and safety as a function focuses on securing and promoting safety and health of the persons working for the company including both physical and mental health (Amahalu et al., 2017). Like most other management function this includes developing and implementing health and safety strategies, measuring and following up on performance issues and report these issues to internal and external stakeholders. Ignoring Health and Safety can be expensive. Resulting effects such as occupational accidents cost money for the companies in which they happen, they lead to financial losses for the employees to whom they happen and they cost society money in health care and loss of working capacity.

\subsection{Environmental Remediation Cost Disclosure}

Environmental remediation costs means all costs and expenses of actions or activities to cleanup or remove hazardous materials from the environment, to prevent or minimize the further movement, leaching or migration of hazardous materials in the environment, prevent, minimize or mitigate the release or threatened release of hazardous materials into the environment, or injury or damage from such release, and comply with the requirements of any environmental laws. environmental remediation costs include, without limitation, costs and expenses payable in connection with the foregoing for legal, engineering or other consultant services, for investigation, testing, sampling, and monitoring, for boring, excavation, and construction, for removal, modification or replacement of equipment or facilities, for labor and material, and for proper storage, treatment, and disposal of Hazardous Materials (Crane \& Scott, 2012).

\subsection{Profitability}

Profitability is the state or condition of yielding a financial profit or gain. Profitability is the ability of a business to earn a profit. A profit is what is left of the revenue a business generates after it pays all expenses directly related to the generation of the revenue, such as producing a product, and other expenses related to the conduct of the business activities (Horton, 2018). Profitability is the primary goal of all business ventures. Without profitability the business will not survive in the long run. So measuring current and past profitability and projecting future profitability is very important. Profitability is measured with income and expenses. Income is money generated from the activities of the business. Expenses are the cost of resources used up or consumed by the activities of the business (Amahalu et al., 2019).

\subsection{Net Profit Margin}

Net profit margin is the ratio of net profits to revenues for a company or business segment. Typically expressed as a percentage, net profit margins show how much of each naira collected by a company as revenue translates into profit (Amahalu et al., 2016).

The equation to calculate net profit margin is: net profit/revenue.

\subsection{Waste Management Cost Disclosure and Net Profit Margin}

Waste management is a serious issue due to its human health and environmental sustainability implications. It is really a pressing issue the world is facing today, since a high percentage of waste is currently disposed of by open dumping (Harts \& Ahuja, 2016).To buttress this assertion (Agbo et al. 2017) posit that Waste Management is a globally challenging issue especially in developing countries, due to its adverse environmental effects. Prior studies that have analysed the relationship between waste 
management cost and profitability found varying results. For instance, Abrate et al. (2014) found a positive relationship between waste management cost and profitability while Jalil (2010) found a negative relationship between waste management cost and profitability on the other hand Ifurueze, Lyndon and Bingilar (2013) found that waste management cost has statistically significant and negative relationship with profitability.

\subsection{Employee Health and Safety Cost Disclosure and Net Profit Margin}

Despite the fact that people are working and spend most of their working hours at the workplace, little attention and resources are accorded to health and safety at work. In emerging economies, workplace safety and health has been overlooked in their industrial development policy and strategies. They are mostly focused on the production volume or profit undermining the latent effect of dissatisfactory working environment. Safe workplaces are profitable workplaces, whether measured in a company's bottom line, its market share, its broader consumer reputation, or its ability to attract and retain workers, managers, or investors. Healthy people are expected to contribute more to productivity and innovation. However, absenteeism from workplace site causes productivity loss. Huang et al. (2012) evidenced that employee health and safety cost has a positive and significant relationship with profitability, while Nordlöf et al. (2015) found no relationship between employee health and safety cost and profitability.

\subsection{Environmental Remediation Cost Disclosure and Net Profit Margin}

The industrial revolutions lead to economic improvement for most people in the industrialized society. These economic developments are not without costs. Industrialization which required the use of natural resources including energy brought about factory pollutant and greater land use, which harmed the natural environment. This is evidenced in environmental degradation and atmospheric pollution generally experienced in the world and particularly in Nigeria today. However, the increase in global environmental awareness and the campaign for sustainable economic development is redirecting the attention of firms towards environmental sensitivity. Sustainable development as is generally known focuses on the creation of wealth and prosperity, whilst considering the true importance of social and environmental aspects, allowing business and public organizations to meet triple bottom line in sustainable management (Mohammad et al., 2013; Norhasimah et al., 2016).

\subsection{Theoretical Framework}

\subsubsection{Cradle to Cradle Theory}

A phrase coined by Walter R. Stahel in the 1970s and popularized by William McDonough and Michael Braungart in (2002). This framework seeks to create production techniques that are not just efficient but are essentially waste free. In cradle-to-cradle production, all material inputs and outputs are seen either as technical or biological nutrients. Technical nutrients can be recycled or reused with no loss of quality and biological nutrients composted or consumed. By contrast, cradle-to-grave refers to a company taking responsibility for the disposal of goods it has produced, but not necessarily putting products' constituent components back into service. Cradle to Cradle concept is a new approach for designing intelligent products, processes and systems taking into account the entire life cycle of the product, optimizing material health, recyclabilty, renewable energy use, water efficiency and quality, and social responsibility.

\subsubsection{Empirical Review}

Amahalu et al. (2017) ascertained how corporate social responsibility (CSR) relates with financial performance of quoted deposit money banks in Nigeria from 2010-2016. Specifically, this study aimed to ascertain the extent of relationship that exists between donation and return on assets; determined the extent of relationship that exists between donation and return on equity and to evaluate the extent of relationship between donations and market-to-book value of quoted deposit money banks in Nigeria. The study employed ex-post fact research design. The sample size of this study consists of the fifteen quoted deposit money banks in Nigeria. Pearson Coefficient Correlation, Panel Least Square (PLS) regression 
analysis and Granger Causality test were employed via E-View 9.0. The study found a significant positive relationship between return on asset, return on equity, market-to-book value and donations at $5 \%$ level of significance. The implication of the findings is that CSR implementation maximizes future returns for deposit money banks in Nigeria. It was recommended among others that since CSR have a positive and significant relationship with financial position, deposit money banks should engage in CSR practices as this will guarantee a safer environment for smooth operations and maximisation of shareholders wealth.

Okafor (2018) ascertained the effect of environmental costs on firm performance. To achieve the objective, the study made use of financial reports of Oil and Gas Companies quoted in the Nigerian Stock Exchange Market from years 2006-2015. Regression analysis was employed with the aid of Statistical Package for Social Sciences (SPSS). The results of the statistical analysis indicated that better environmental performance positively impact business value of an organization. Moreover, environmental accounting provides the organization an opportunity to reduce environmental and social costs and improve their performance.

Nyirenda et al. (2018) examined the impact of environmental management practices on the financial performance of a South African mining firm. The major aim of the study was to investigate whether such practices have a close relationship with the mining firm's financial performance (represented by return on equity $[R O E])$. The approach was a case study of a South African mining firm listed under the socially responsible index (SRI) of the Johannesburg Stock Exchange (JSE). It uses Green-Steel (pseudonym used in place of the real name) as a case study. Using multiple regression statistics, the return on equity of GreenSteel regressed on three environmental management practices of Green-Steel (carbon reduction, energy efficiency, and water usage). The result showed there is no significant relationship between the variables and this lends credence to information gathered from Green-Steel environmental reports that GreenSteel's environmental management practices are driven mostly by a desire to abide by regulations and also by a moral obligation to use environmental management practices to mitigate climate change impact.

\section{Methodology of research}

\subsection{Research Design}

The research designs employed in this study are content analysis and ex-post facto research design. Content analysis method is concerned with the number of words and sentences on particular information while ex-post facto research design, was utilised in order to establish the meaningful relationship between environmental cost disclosure and profitability.

\subsection{Population of the Study}

The population of this study consists of all the of the fifty four (54) upstream oil and gas companies listed on the Nigerian Stock Exchange as at 31 ${ }^{\text {st }}$ December, 2019 (refer to appendix I).

\subsection{Sample Size and Sampling Method}

Eleven (11) Oil and Gas companies were selected as the sample size of this study with the utilization of Purposive sampling method. They are: Chevron Nigeria; ELF Petroleum Nigeria (EPNL); Mobil Producing Nigeria; Nexen Petroleum Nigeria; Nigerian Agip Oil (NAOC); Shell Petroleum Development Company of Nigeria; Amni International Petroleum Development; Camac Nigeria; Conoil Producing Company; Nigerian National Petroleum Corporation (NNPC); Yinka Folawiyo Petroleum Company. Data were gathered from the published financial statements of the eleven (11) Oil and Gas companies for a ten (10) year period spanning from 2010-2019, using Purposive sampling method.

\subsection{Source of Data}

This study made use of secondary data precisely. The data were sourced from publications of the Nigerian stock exchange (NSE), fact books and the annual report and accounts of the selected quoted Oil and Gas companies and stand-alone sustainability report. 


\subsection{Data Analysis Technique}

This study adopted the Global Reporting Initiative (GRI) framework disclosures according to the G4 guidelines for the purpose of developing the Environmental cost disclosure index. Environmental cost disclosure was evaluated by 34 indicators on policies and systems on social, economic and environmental issue: Employment; Labour/Management Relations; Occupational Health and Safety; Training and Education; Diversity and Equal Opportunity; Equal Remuneration for Women and Men; Investment and Procurement Practices; Non-discrimination; Freedom of Association and Clooective Bargaining; Child Labour; Forced and Compulsory Labour; Security Practices; Indigenous Rights; Assessment; Remediation; Local Communities; Corruption; Public Policy; Anti-Competitive Behaviour; Compliance; Customer Health and Safety; Product and Service Labelling; Market Communications; Customer Privacy; Market Presence; Indirect Economic Impacts; Materials; Energy; Water; Biodivrsity; Emissions, Effluents and Waste; Products and Services; Compliance; Transport.

All the above indicators were rated on a scale from 0 to 3 points. When a company does not take into account the specific indicator at all, it is rated with 0 (i.e non-reporting). A company is ranked 1 or 2 depending on the broadness of the description (e.g. 1 if the company only names the indicator and 2 if there is a very poor or unclear description (partial reporting). The company is rated 3 if it takes the indicator into consideration with a satisfying description (full disclosure). So, a total score for environmental costs disclosure could reach the maximum score of 102 (i.e $3 \times 34$ ).

Therefore,

$E C D I=T D P / M P$

Where;

$\mathrm{ECDI}=$ Environmental Cost Disclosure Index

TDP $=$ Total Disclosure Points of a firm

MP = Maximum Points for a firm (102)

\subsection{Research Variables}

\section{Independent Variables}

The independent variable in this study is environmental cost disclosure which was proxied with:

Waste Management Cost, Employee Health and Safety Cost, and Environmental Remediation Cost:

i) Waste Management Cost (WMC): Obtained from the annual reports and accounts of the respective sampled companies for the study period (various issues).

ii) Employee Health and Safety Cost (EHSC): Obtained from the annual reports and accounts of the respective sampled companies for the study period (various issues)

iii) Environmental Remediation Cost: Obtained from the annual reports and accounts of the respective sampled companies for the study period (various issues).

\section{Dependent Variables}

The dependent variable which is Profitability was measured with:

i. Net Profit Margin:

Net profit margin is the percentage of revenue left after all expenses have been deducted from sales. The measurement reveals the amount of profit that a business can extract from its total sales.

Net Profit Margin $=($ Net profits $\div$ Net sales $) \times 100$

Control Variables

In conducting the linear multiple regression analysis, the following control variables were included:

(a) Size of the firm (FSZ): Size of the firm as measured by the natural log of total assets, is used to control the impact of size on wealth creation.

(b) Leverage (LEV):

Financial leverage as measured by total debt divided by total equity is used to control the impact of debt servicing on corporate performance and wealth creation 
LEV $=\underline{\text { Total debt }}$

Total equity

\subsection{Model Specification}

The following research models were formulated in line with the research hypotheses in order to empirically determine the effect of environmental cost disclosure on profitability.

$$
\begin{aligned}
& N P M_{i t}=\beta_{0}+\beta_{1} W_{M C} i t+\beta_{2} L E V_{i t}+\beta_{3} F_{S Z} i t+\mu_{i t} \quad-\quad \text { Model } 1 \\
& N P M_{i t}=\beta_{0}+\beta_{1} E_{H S C} C_{i t}+\beta_{2} L E V_{i t}+\beta_{3} F_{S Z}+\mu_{i t}-\text { Model } 2 \\
& N P M_{i t}=\beta_{0}+\beta_{1} E R C_{i t}+\beta_{2} L E V_{i t}+\beta_{3} F S Z_{i t}+\mu_{i t} \quad-\quad \text { Model } 3
\end{aligned}
$$

Where:

$N P M_{i t}=$ Net Profit Margin of firm $i$ in period $t$

$W_{M C} C_{i t}=$ Waste Management Cost of firm $i$ in period $t$

$\mathrm{CDC}_{\text {it }}=$ Community Development Cost of firm $i$ in period $t$

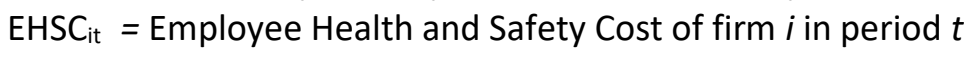

$\mathrm{ERC}_{\text {it }}=$ Environmental Remedial Cost of firm $i$ in period $t$

$\mathrm{FSZ}_{\text {it }}=$ Firm Size of firm $i$ in period $t$

$\mathrm{LEV}_{\text {it }}=$ Leverage of firm $i$ in period $t$

$\mu_{i, t}=$ component of unobserved error term of firm $i$ in period $t$

$\beta_{0}=$ constant term

$\beta_{1}, \beta_{2}, \beta_{3}$ and $\beta_{4}=$ are slope to be estimated of firm $i$ in period $t$.

$i=$ firm identifier (11 firms)

$\mathrm{t}=$ time variable $(2010,2011, \ldots$ 2019) - (Ten Years)

\subsection{Presentation and Analysis of Data}

Table 1. Pearson Correlation Matrix

* (8 variables, 110 observations pasted into data editor)

. correlate npm wmc cdc ehsc erc fsz lev (obs $=110$ )

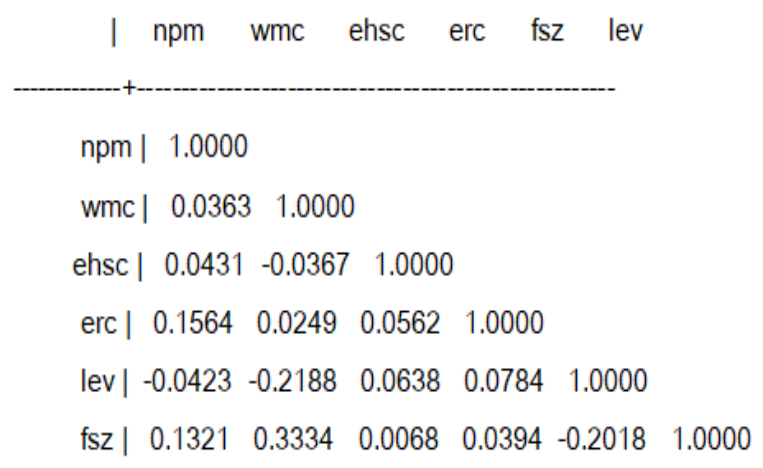

Source: STATA 13, Pearson correlation output, 2020

\subsection{Interpretation on Pearson Correlation Matrix}

From the findings on the correlation analysis in table 1 , the study found that there is a positive correlation coefficient between WMC, EHSC, ERC, FSZ and NPM by a coefficient value of $0.0363,0.0254$, $0.0431,0.1564$ and 0.0 .1321 respectively, while the coefficient of -0.0423 indicates that NPM negatively correlates with LEV.

\subsection{Research Hypotheses}

Test of Hypothesis I

Ho $_{1}$ : Waste Management Cost has no significant effect on Net Profit Margin of Oil and Gas Companies listed on Nigeria Stock Exchange. 
$\mathbf{H}_{1}$ : Waste Management Cost has significant effect on Net Profit Margin of Oil and Gas Companies listed on Nigeria Stock Exchange.

Table 2. Panel Least Square Regression analysis showing the effect WMC on NPM

. Regress npm wmc lev fsz

\begin{tabular}{|c|c|c|c|}
\hline Source | & $\mathrm{df}$ & MS & Number of obs $=110$ \\
\hline & - & & $F(3,106)=9.93$ \\
\hline Model| 1.15737147 & 3 & .385790491 & Prob $>F=0.0062$ \\
\hline Residual| 44.008811 & 106 & .415177463 & R-squared $=0.6456$ \\
\hline & & & Adj R-squared $=0.6120$ \\
\hline Total | 45.1661825 & 109 & .414368647 & Root MSE $=.64434$ \\
\hline
\end{tabular}

\begin{tabular}{lllllllll}
\hline npm | & Coef. & Std. Err. & $\mathrm{t}$ & $\mathrm{P}>|\mathrm{t}|$ & \multicolumn{3}{l}{ [95\% Conf. Interval] } \\
\hline wmc | & .0762205 & .0820714 & 3.93 & 0.001 & .2389351 & .0864941 \\
lev | & -.0158481 & .0500231 & -2.72 & 0.032 & .1150237 & .0833275 \\
fsz | & .0405253 & .0264031 & 5.53 & 0.000 & .0118214 & .092872 \\
_cons | & .6480437 & .5973302 & 5.08 & 0.000 & .5362215 & 1.832309
\end{tabular}

Source: STATA 13, Regression Output, 2020

\subsection{Interpretation of Regression Coefficient Result}

The following regression equation was obtained from table 2 :

$\mathrm{NPM}=0.6480437+0.0762205 \mathrm{WMC}-0.0158481 \mathrm{LEV}+0.0405253 \mathrm{FSZ}$

Using the above model, it is possible to determine the relationship between WMC, LEV, FSZ and NPM of listed oil and gas firms. Holding all other factors constant, an increase in one unit of the WMC results into 0.076 increase of NPM, while a unit decrease in LEV will lead to 0.016 corresponding increase of NPM, and a unit increase in FSZ will result to 0.041 increase of NPM. The slope coefficient $\left(\beta_{1}=0.0762205\right)$ showed that waste management cost relates positively with NPM, with a t-statistic of 3.93 and associated $P>|t|$ value of $0.036<0.05$. This implies that waste management cost has a significant positive relationship with NPM at $5 \%$ level of significance. Results in table 2 indicated that the adjusted R-squared for the model is 0.612 , meaning that the regression model used for this study is a good predictor. The independent variables explained $61.2 \%$ of the variation in NPM of listed oil and gas firms. Only $38.8 \%$ of variation in NPM of listed oil and gas firms is not explained by the regression model. From the test of coefficients result in table 2 , the probability value of the F-statistics $=0.0062$ implies that the regression model is significant in predicting the effect of waste management cost on net profit margin. The significance between the variables is less than $\alpha=0.05$. This result indicates that the overall regression model is statistically significant and is useful for prediction purposes at $5 \%$ significance level.

Decision

Going by the rule of thumb, since the Prob(F-statistic) of the test $=0.0062$ is less than the $\alpha$-value value of 0.05 ; therefore $\mathrm{H}_{1}$ is accepted, which upholds that waste management cost has a significant positive effect on net profit margin of oil and gas companies listed on Nigeria Stock Exchange at $5 \%$ level of significance.

Test of Hypothesis II

$\mathrm{Ho}_{2}$ : Employee Health and Safety Cost has no significant effect on Net Profit Margin of Oil and Gas Companies listed on Nigeria Stock Exchange.

$\mathbf{H}_{2}$ : Employee Health and Safety Cost has significant effect on Net Profit Margin of Oil and Gas Companies listed on Nigeria Stock Exchange. 
Table 3. Panel Least Square Regression analysis showing the effect EHSC on NPM . regress npm ehsc lev fsz

\begin{tabular}{|c|c|c|c|c|c|c|c|}
\hline \multirow[t]{2}{*}{ Source | } & \multirow[t]{2}{*}{ SS } & \multirow[t]{2}{*}{$\mathrm{df}$} & \multirow{2}{*}{\multicolumn{2}{|c|}{ MS }} & \multicolumn{3}{|c|}{ Number of obs $=110$} \\
\hline & & & & & \multicolumn{3}{|c|}{$F(3,106)=6.70$} \\
\hline Model | & 882851902 & 3 & \multicolumn{2}{|c|}{.294283967} & \multicolumn{3}{|c|}{ Prob $>F=0.0334$} \\
\hline \multirow{2}{*}{\multicolumn{2}{|c|}{ Residual| 44.2833306}} & 106 & \multicolumn{2}{|c|}{.41776727} & \multicolumn{3}{|c|}{ R-squared $=0.4195$} \\
\hline & & & & & \multirow{2}{*}{\multicolumn{3}{|c|}{$\begin{array}{l}\text { Adj R-squared }=0.3082 \\
\text { Root MSE }=.64635\end{array}$}} \\
\hline \multicolumn{2}{|c|}{ Total | 45.1661825} & 109 & \multicolumn{2}{|c|}{.414368647} & & & \\
\hline npm | & Coef. & Std. & & $t$ & $P>1$ & {$[95 \% \mathrm{Co}$} & onf. Interval \\
\hline ehsc| & .0519227 & .116 & 903 & 3.45 & 0.005 & .1782377 & .282083 \\
\hline lev | & -.0067461 & .049 & 086 & -0.14 & 0.892 & -.1050999 & .0916077 \\
\hline fsz | & .0333325 & .025 & 486 & 1.32 & 0.190 & -.0167252 & .0833903 \\
\hline _cons | & .4696172 & .595 & & 2.79 & 0.030 & .710854 & 1.650088 \\
\hline
\end{tabular}

Source: STATA 13, Regression Output, 2020

\subsection{Interpretation of Regression Coefficient Result}

The following regression equation was obtained from table 3 : $\mathrm{NPM}=0.4696172+0.0519227 \mathrm{EHSC}-0.0067461 \mathrm{LEV}+0.0333325 \mathrm{FSZ}$

Using the above model, it is possible to determine the relationship between EHSC, LEV, FSZ and NPM of listed oil and gas firms. Holding all other factors constant, an increase in one unit of the EHSC results into 0.052 increase of NPM, while a unit decrease in LEV will lead to 0.007 corresponding increase of NPM, and a unit increase in FSZ will result into 0.033 increase of NPM. The slope coefficient $\left(\beta_{1}=0.0519227\right)$ revealed that employee health and safety cost relates positively with NPM, with a t-statistic of 3.45 and associated $\mathrm{P}>|\mathrm{t}|$ value of $0.005<0.05$. This implies that employee health and safety cost has a significant positive relationship with NPM at 5\% level of significance. Results in table 3 indicated that the adjusted R-squared for the model is 0.308 , meaning that the regression model used for this study is a good predictor. The independent variables explained $30.8 \%$ of the variation in NPM of listed oil and gas firms. Only $69.2 \%$ of variation in NPM of listed oil and gas firms is not explained by the regression model. From the test of coefficients result in table 3 , the probability value of the F-statistics $=0.0334$ implies that the regression model is significant in predicting the effect of employee health and safety cost on net profit margin. The significance between the variables is less than $\alpha=0.05$. This result indicates that the overall regression model is statistically significant and is useful for prediction purposes at $5 \%$ significance level.

\section{Decision}

Going by the rule of thumb, since the Prob(F-statistic) of the test $=0.0334$ is less than the $\alpha$-value value of 0.05 ; therefore $\mathrm{H}_{1}$ is accepted, which upholds that employee health and safety cost has a significant positive effect on net profit margin of oil and gas companies listed on Nigeria Stock Exchange at $5 \%$ level of significance.

Test of Hypothesis III

Ho $_{3}$ : Environmental Remediation Cost has no significant effect on Net Profit Margin of Oil and Gas Companies listed on Nigeria Stock Exchange.

$\mathbf{H}_{3}$ : Environmental Remediation Cost has significant effect on Net Profit Margin of Oil and Gas Companies listed on Nigeria Stock Exchange. 
Table 4. Panel Least Square Regression analysis showing the effect ERC on NPM

. regress npm erc lev fsz

\begin{tabular}{|c|c|c|c|c|c|c|c|}
\hline Source I & SS & df & \multicolumn{2}{|c|}{ MS } & \multicolumn{3}{|c|}{ Number of obs $=110$} \\
\hline Model | & 1.96900853 & 3 & \multicolumn{2}{|c|}{.65633617} & \multicolumn{3}{|c|}{ Prob $>F=0.0073$} \\
\hline Residual | & 43.197174 & 106 & \multicolumn{2}{|c|}{.407520509} & \multicolumn{3}{|c|}{ R-squared $=0.6436$} \\
\hline & & & \multirow{2}{*}{\multicolumn{2}{|c|}{.414368647}} & \multicolumn{3}{|c|}{ Adj R-squared $=0.6165$} \\
\hline Total | & 5.1661825 & 109 & & & \multicolumn{3}{|c|}{ Root MSE = .63837 } \\
\hline npm | & Coef. & Std & & $\mathrm{t}$ & $P>|t|$ & \multicolumn{2}{|c|}{ [95\% Conf. Interval] } \\
\hline erc $\mid$ & .0836545 & .04 & 766 & 4.69 & 0.000 & .1815485 & .0142395 \\
\hline lev | & -.000883 & .04 & 793 & -0.02 & 0.986 & -.0981874 & .0964215 \\
\hline fsz | & .0354985 & .02 & & 3.42 & 0.003 & .0140108 & .0850078 \\
\hline _cons | & .5960403 & .57 & 498 & 3.03 & 0.008 & -.5499997 & 1.74208 \\
\hline
\end{tabular}

Source: STATA 13, Regression Output, 2020

\subsection{Interpretation of Regression Coefficient Result}

The following regression equation was obtained from table 4:

$\mathrm{NPM}=0.5960403+0.0836545 \mathrm{ERC}-0.000883 \mathrm{LEV}+0.0354985 \mathrm{FSZ}$

Using the above model, it is possible to determine the relationship between ERC, LEV, FSZ and NPM of listed oil and gas firms. Holding all other factors constant, an increase in one unit of the ERC results into 0.084 increase of NPM, while a unit decrease in LEV will lead to 0.001 corresponding increase of NPM, and a unit increase in FSZ will result into 0.035 increase of NPM. The slope coefficient $\left(\beta_{1}=0.0836545\right)$ revealed that environmental remediation cost relates positively with NPM, with a t-statistic of 4.69 and associated $\mathrm{P}>|\mathrm{t}|$ value of $0.000<0.05$. This implies that environmental remediation cost has a significant positive relationship with NPM at $5 \%$ level of significance. Results in table 4 indicated that the adjusted R-squared for the model is 0.617 , meaning that the regression model used for this study is a good predictor. The independent variables explained $61.7 \%$ of the variation in NPM of listed oil and gas firms. Only $38.3 \%$ of variation in NPM of listed oil and gas firms is not explained by the regression model.

From the test of coefficients result in table 4.5, the probability value of the F-statistics $=0.0073$ implies that the regression model is significant in predicting the effect of environmental remediation cost on net profit margin. The significance between the variables is less than $\alpha=0.05$. This result indicates that the overall regression model is statistically significant and is useful for prediction purposes at $5 \%$ significance level.

Decision

Going by the rule of thumb, since the Prob(F-statistic) of the test $=0.0073$ is less than the $\alpha$-value value of 0.05 ; therefore $H_{1}$ is accepted, which upholds that environmental remediation cost has a significant positive effect on net profit margin of oil and gas companies listed on Nigeria Stock Exchange at $5 \%$ level of significance.

\section{Findings, conclusions and recommendations}

\subsection{Summary of findings}

Based on the analysis of this study, the following findings were made:

i. Waste management cost has a significant positive effect on net profit margin of oil and gas companies listed on Nigeria Stock Exchange at $5 \%$ level of significance.

ii. Employee health and safety cost has a significant positive effect on net profit margin of oil and gas companies listed on Nigeria Stock Exchange at 5\% level of significance. 
iii. Environmental remediation cost has a significant positive effect on net profit margin of oil and gas companies listed on Nigeria Stock Exchange at 5\% level of significance.

\subsection{Conclusions}

The thrust of this study was to ascertain the effect of environmental cost disclosure (proxied by waste management cost disclosure, employee health and safety cost disclosure and environmental remediation cost disclosure) on profitability (measured by net profit margin) of oil and gas firms listed on Nigeria Stock Exchange between 2010 and 2019. Panel data were obtained from annual reports and accounts of the sampled firms for the study period, using eleven (11) listed upstream oil and gas firms in Nigeria. Regression analysis was employed via STATA 13. The results of the tested hypotheses revealed that; environmental cost disclosure indices have a significant positive effect on net profit margin at $5 \%$ level of significance respectively.

\subsection{Recommendations}

The following recommendations were proffered:

i. Due attention should be paid to waste management costs by oil and gas firms since such costs influence strategic decision.

ii. Indigenous and multi-national firms should ensure that all the strict policies as regards employees' health and safety are adhered to in the course of their operation, in a bid to adding value to the organization.

iii. Since environmental remediation cost is value relevant in making strategic business decision. Thus, it was recommended that firms should constantly reposition their accounting system in order to provide information on environmental remediation so that the true costs in an organization can be ascertained and properly allocated.

\section{References}

1. Abrate, G., Erbetta, F., Fraquelli, G., \& Vannoni, D. (2014). The costs of disposal and recycling: An application to Italian municipal solid waste services. Regional Studies 48 (5), 896-909.

2. Agbo, B. O., Ohaegbu, O. K., \& Akubuilo, F. (2017). The effect of environmental cost on financial performance of Nigerian brewery. European Journal of Business and Management, 9(17), 59-64.

3. Amahalu, N. N., Agbionu, U. C., \& Obi, C. J. (2017). Effect of human resource accounting on profitability of selected quoted telecommunication firms in Nigeria. Contemporary Issues in Business Management: A Multidisciplinary Approach, 410-443.

4. Amahalu, N. N., Egolum, P. U., Obi, J. C., \& Iliemena, R. O. (2016). Corporate governance and organizational profitability: Empirical evidence from quoted natural resources firms in Nigeria. Managing diversification for sustainable development in sub-saharan Africa, Faculty of Management Sciences, 2016. International Conference, 8-10, November, 2016.

5. Amahalu, N. N., Egolum, P. U., \& Obi, J. C. (2019). Effect of e-accounting systems on financial performance of quoted deposit money banks in Nigeria. Faculty of Management Sciences, 2019 International Conference Proceedings, Nnamdi Azikiwe University, Awka, Anambra State, Nigeria, 437-449.

6. Amahalu, N. N., Ezechukwu, B. O., \& Obi, J. C. (2017).Corporate social responsibility and financial performance of quoted deposit money banks in Nigeria. Asian Journal of Science and Technology, 08(12), 7183-7191.

7. Amahalu, N. N., Okoye, P. V., \& Obi, J. C. (2018). Effect of sustainability reporting on economic value added of quoted brewery firms in Nigeria. Journal of Accounting, 7(1), 1-20.

8. Crane, R. A., \& Scott, T. B. (2012). Nanoscale zero-valent iron: Future prospects for an emerging water treatment technology. Journal of Hazardous Materials. 211-212: 112-25. doi:10.1016/j.jhazmat.2011.11.073. PMID 22305041

9. Dijkgraaf, E., \& Gradus, R. (2017). Collusion in the Dutch waste collection market. Local Government Studies, 33(4), 573-88.

10. Ezeokafor, F. C., \& Amahalu, N. N. (2019). Effect of sustainability reporting on corporate performance of quoted oil and gas firms in Nigeria. Journal of Global Accounting, 6(2), 217-228. 
11. Glossary of Environment Statistics. (2001). Studies in Methods, Series F, No. 67, United Nations, New York, 2001.

12. Harts, S. L., \& Ahuja, G. (2016). Does it pay to be green? An empirical examination of the relationship between emission reduction and firm performance. Business Strategy and the Environment, 5(1), 30-37.

13. Horton, M. (2018). What is the difference between profitability and profit? https://www.investopedia.com/ask/answers/012715/what-difference-between-profitability-and-profit.asp. Retrieved 12/5/2018.

14. Huang, Y., Verma, S. K., Chang, W., Courtney, T. K., Lombardi, D. A., Brennan, M. J., \& Perry, M. J. (2012). Management commitment to safety vs. employee perceived safety training and association with future injury. Accident Analysis \& Prevention, 47, 94-101.

15. Ifurueze, M. S. K., Lyndon, M. E., \& Bingilar, P. F. (2013). The impact of environmental cost on corporate performance: A study of oil companies in Niger Delta states of Nigeria. Journal of Business \& Management, 2(2), 01-10.

16. Jalil, A. (2010). Sustainable development in Malaysia: A case study on household waste management. Sustainable Development 3(3), 91-102.

17. Judge, W. Q., \& Douglas, Y. T. (2018). Performance implications of incorporating natural environmental issues into the strategic planning process: An empirical assessment. Journal of Management Studies, 35(2), 241-262.

18. King, A., \& Lenox, M. (2010). Industry self-regulation without sanctions: The chemical industry's responsible care program, Academy of Management Journal 43, 698-716.

19. Mohammad, I., Sutrisno, T., Prihat, A., \& Rosidi. (2013). Effect of environmental accounting implementation and environmental performance and environmental information disclosure as mediation on company value. International Journal of Business and Invention 2(10) 55-67.

20. Nordlöf, H., Wiitavaara, B., Winblad, U., Wijk, K., Westerling, R. (2015). Safety culture and reasons for risk-taking at a large steel-manufacturing company: Investigating the worker perspective. Safety Science, 73, 126-135.

21. Norhasimah, M. N., Aishah, S. B., Nor-Amiera, A., Sheh-Muhammad, Q. A., \& Inaliah, M. A. (2016). The effects of environmental disclosure on financial performance in Malyasia. Procedia Economics and Finance 35, 117-126.

22. Norhasimah, M. N., Aishah, S. B., Nor-Amiera, A., Sheh-Muhammad, Q. A., \& Inaliah, M. A. (2016). The effects of environmental disclosure on financial performance in Malyasia. Procedia Economics and Finance 35, 117-126.

23. Nyirenda, G., Ngwakwe, C. C., \& Ambe, C. M. (2018). Environmental management practices and firm performance in a South African mining firm. Managing Global Transitions 11(3), 243-260.

24. Okafor, T. G. (2018).Environmental costs accounting and reporting on firm financial performance: A survey of quoted Nigerian oil companies. International Journal of Finance and Accounting, $7(1), 1-6$.

25. Rockness, J., Schlachter, P., \& Rockness, H. O. (2016). Hazardous waste disposal, corporate disclosure, and financial performance in the chemical industry. In: Neimark, M. (Ed.), Advances in Public Interest Accounting, 1, JAI Press, Greenwich, pp. 67-191.

26. Rodriguez, F. J., \& Cruz, Y. M. (2017), Relationship between social-environmental responsibility and performance in hotel firms. Hospitality Management, 26, 824-839.

27. Russo, M. V., \& Fouts, P. A. (2017). A resource-based perspective on corporate environmental performance and profitability. Academy of Management Journal 40(3), 534-559.

28. Thornton, D., Kagan, R. A., \& Gunningham, N. (2013). Sources of corporate environmental performance. California Management Review 46 (1), 127-141.

29. Worrell, D. L., Gilley, K. M., Davidson, III, W. N., \& El-Jelly, A. (2015). When green turns to red: Stock market reaction to announced greening activities. Proceeding of the Academy of Management Meeting: held at Vancouver, Canada, 1-3. 
Listed Upstream Oil \& Gas Companies in Nigeria

\section{Appendix I}

\section{Population of the Study}

1. ADDAX PETROLEUM DEVELOPMENT (NIGERIA)

2. ADDAX PETROLEUM EXPLORATION (NIGERIA)

3. AGIP ENERGY \& NATURAL RESOURCES (NIGERIA)

4. BRASS EXPLORATION

5. CHEVRON NIGERIA

6. CONOCO ENERGY NIGERIA

7. CONOCO PETROLEUM NIGERIA

8. ELF PETROLEUM NIGERIA (EPNL)

9. ESSO EXPLORATION \& PRODUCTION (NIGERIA) (EEPNL)

10. HARDY OIL NIGERIA

11. MOBIL PRODUCING NIGERIA

12. NEXEN PETROLEUM NIGERIA

13. NIGERIAN AGIP EXPLORATION (NAE)

14. NIGERIAN AGIP OIL (NAOC)

15. PETROLEO BRASILEIRO NIGERIA

16. PHILLIPS OIL COMPANY (NIGERIA)

17. SHELL NIGERIA EXPLORATION \& PRODUCTION (SNEPCO)

18. SHELL PETROLEUM DEVELOPMENT COMPANY OF NIGERIA

19. STAR DEEP WATER PETROLEUM

20. STATOIL NIGERIA

21. SYNTROLEUM NIGERIA

22. TEXACO NIGERIA OUTER SHELF

23. TEXACO OVERSEAS (NIGERIA) PETROLEUM (TOPCON)

24. TOTAL UPSTREAM NIGERIA

25. AFREN ENERGY RESOURCES

26. ALFRED JAMES PETROLEUM

27. ALLIED ENERGY RESOURCES (NIGERIA)

28. AMALGAMATED OIL

29. AMNI INTERNATIONAL PETROLEUM DEVELOPMENT

30. ATLAS ORANTO PETROLEUM OIL

31. CAMAC NIGERIA

32. CONOIL PRODUCING

33. DUBRI OIL

34. EQUATOR EXPLORATION NIGERIA

35. EXPRESS PETROLEUM \& GAS

36. FAMFA OIL

37. MIDLANTIC INTERNATIONAL

38. MILLENIUM OIL \& GAS COMPANY (MOGCL)

39. MONI PULO

40. NIGERIAN NATIONAL PETROLEUM CORPORATION (NNPC)

41. NIGER DELTA PETROLEUM RESOURCES

42. NIGERIAN PETROLEUM DEVELOPMENT COMPANY (NPDC)

43. NOREAST PETROLEUM

44. OILWORLD

45. OPTIMUM PETROLEUM DEV.

46. ORIENT PETROLEUM RESOURCES LIMITED

47. ORIENTAL ENERGY RESOURCES

48. PAN OCEAN OIL CORP. (NIGERIA)

49. SAHARA ENERGY FIELDS

50. SOLGAS PETROLEUM

51. SOUTH ATLANTIC PETROLEUM (SAPETRO)

52. SUMMIT OIL INTERNATIONAL

53. SUNLINK PETROLEUM

54. YINKA FOLAWIYO PETROLEUM 